\title{
Exhaled NO during graded changes in inhaled oxygen in man
}

Leopold Schmetterer, Karin Strenn, Johannes Kastner, Hans-Georg Eichler, Michael Wolzt presumably mediated by decreased production of endogenous NO. ${ }^{9}$ Several investigators have shown that hypoxia decreases exhaled NO levels in isolated animal lungs. ${ }^{10-12}$ The aim of the present study was to investigate whether oxygen tension affects exhaled NO levels in humans. However, due to ethical considerations any study on this subject in humans is limited to moderate hypoxia. We have therefore included different grades of hypoxia and hyperoxia in the present study to obtain a dose-response relationship between changes in inhaled oxygen and exhaled NO.

\section{Methods}

SUBJECTS

Sixteen healthy, non-smoking, drug-free volunteers (nine men) of mean (SD) age 28.6 (3.2) years (range 23-35) were studied. None of the subjects reported airway hyperreactivity or lung disease in their medical history.

The study protocol was approved by the ethics committee of Vienna University School of Medicine and written informed consent was obtained from all subjects.

\section{PILOT STUDY}

In four of the subjects we performed experiments on the effect of inhalation of $100 \%$ $\mathrm{O}_{2}$ and $10 \% \mathrm{O}_{2}+90 \% \mathrm{~N}_{2}$ on arterial oxygen tension $\left(\mathrm{PaO}_{2}\right) . \mathrm{PaO}_{2}$ was measured at baseline and at the end of 10 minutes inhalation of $10 \%$ $\mathrm{O}_{2}+90 \% \mathrm{~N}_{2}$ or $100 \% \mathrm{O}_{2}$. The washout period between the two inhalation periods was 10 minutes. $\mathrm{PaO}_{2}$ was determined from capillary blood samples of the earlobe. ${ }^{13}$ The arterialised blood was drawn into a thin glass capillary tube. Arterial $\mathrm{pH}, \mathrm{PCO}_{2}$ and $\mathrm{PO}_{2}$ were determined with an automatic blood gas analysis system (AVL 995-Hb, Graz, Austria). piratory system and in the pathophysiology of airway disease. ${ }^{45}$ The absolute concentration of NO in expired air is dependent on the technique used to measure the exhalate. Exhaled NO is greater during nose breathing than during mouth breathing ${ }^{6}$ and breath holding increases exhaled $\mathrm{NO}^{7}$ which suggests accumulation of $\mathrm{NO}$ in the upper and lower respiratory tract.

In the pulmonary circulation hypoxia causes pulmonary vasoconstriction in vivo. ${ }^{8}$ This effect is specific to the pulmonary vasculature and is
STUDY PROTOCOL

Subjects were randomised to inhale different gas mixtures of $\mathrm{O}_{2}$ and $\mathrm{N}_{2}$ in a double blind crossover design. Studies were conducted on a single trial day. The following gas mixtures of $\mathrm{O}_{2}$ and $\mathrm{N}_{2}$ were administered: $100 \% \mathrm{O}_{2}+0 \%$ $\mathrm{N}_{2}, 80 \% \mathrm{O}_{2}+20 \% \mathrm{~N}_{2}, 60 \% \mathrm{O}_{2}+40 \% \mathrm{~N}_{2}$, $40 \% \mathrm{O}_{2}+60 \% \mathrm{~N}_{2}, 30 \% \mathrm{O}_{2}+70 \% \mathrm{~N}_{2}, 20 \%$ $\mathrm{O}_{2}+80 \% \mathrm{~N}_{2}, 15 \% \mathrm{O}_{2}+85 \% \mathrm{~N}_{2}$, and $10 \%$ 


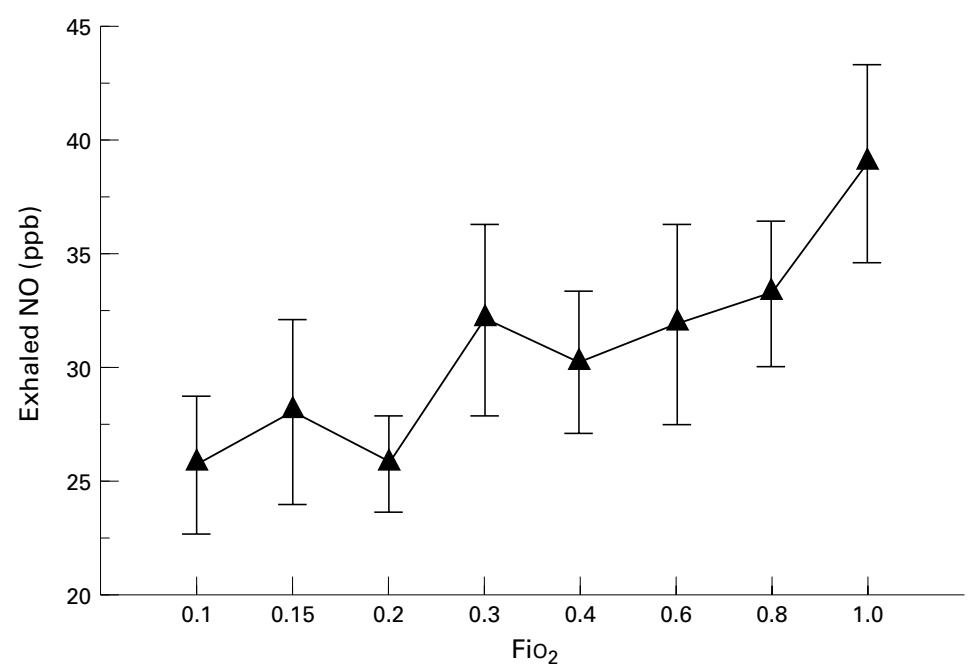

Figure 1 The effect of different mixtures of $\mathrm{O}_{2}$ and $\mathrm{N}_{2}\left(\mathrm{FiO}_{2}\right)$ on exhaled $\mathrm{NO}$ in 16 healthy volunteers. The error bars represent the SE.

$\mathrm{O}_{2}+90 \% \mathrm{~N}_{2}$. Balanced randomisation was used to ensure that groups of two of the 16 subjects received one of the above treatments first. All gases were delivered through a partially expanded reservoir bag at atmospheric pressure under nasal occlusion.

All subjects were asked to refrain from alcohol and caffeine for at least 12 hours before each trial day. After a 20 minute resting period in the sitting position, baseline measurements of exhaled NO and systemic haemodynamics were performed. Thereafter, a 10-minute breathing period of the first gas mixture was started. Measurements were obtained during the last three minutes of each breathing period. Subjects subsequently crossed over to the next treatment where measurements were performed in an identical fashion. The washout period between consecutive inhalation periods was 10 minutes. After four inhalation periods measurements were again performed under resting conditions before crossing over to the other gas mixtures under study. Recordings during breathing of ambient air were repeated at the end of the study. The readouts during breathing of ambient air were taken to calculate short term variability of measurements.

\section{STUDY METHODS}

Exhaled NO was measured with a chemiluminescence detector (Nitrogen oxides analyser, Model 8840, Monitor Labs Inc, USA). Calibration of the instrument was done with certified gases (1000 and $300 \mathrm{ppb} \mathrm{NO}$ in $\mathrm{N}_{2}$, AGA, Vienna, Austria) using precision flow meters. A baseline signal was obtained with pure $\mathrm{N}_{2}$. With $100 \% \mathrm{O}_{2}$ we did not obtain a signal, which ensured that oxygen itself did not influence the NO readings. One $1 / \mathrm{min}$ of the exhaled air was allowed to enter the inlet port. Subjects were instructed to fully inflate their lungs, hold their breath for 10 seconds, and exhale for 10 seconds into a Teflon tube. Autoinhalation of NO from the nasopharynx was avoided by a noseclip. Three consecutive read- ings were made at each measurement point under nasal occlusion. The end expiratory values from the strip recorder readings were used for analysis to ensure that inspired NO from the ambient air did not distort the results. Previous studies have shown that inhalation of up to $38 \mathrm{ppb} \mathrm{NO}$ does not influence the level of exhaled NO after breath holding for 15 seconds. ${ }^{3}$ The detection limit of this method is 2 ppb. ${ }^{14}$

Systolic and diastolic blood pressures and pulse rate were measured by an automated oscillometric device (Siemens Sirecust 888R, Siemens, Erlangen, Germany).

STATISTICAL ANALYSIS

Statistical analysis was performed using the Statistica software package (Release 4.5, StatSoft Inc, Tulsa, Oklahoma, USA). To quantify the short term variability of the exhaled NO measurements, intraclass correlation coefficients $(\kappa)$ were calculated from the three recordings under ambient air breathing. $\kappa$ was calculated according to the method of Kramer and Feinstein ${ }^{15}$ based on a repeated measure ANOVA model. $\kappa$ can then be calculated from the variance among subjects $\left(v_{s}\right)$, the variance among methods $\left(\mathrm{v}_{\mathrm{m}}\right)$, and the residual error variance $\left(\mathrm{v}_{\mathrm{e}}\right)$ :

$$
\kappa=\left(\mathrm{v}_{\mathrm{s}}-\mathrm{v}_{\mathrm{e}}\right) /\left(\mathrm{v}_{\mathrm{s}}+\mathrm{v}_{\mathrm{e}}+2 \times \mathrm{v}_{\mathrm{m}}\right)
$$

The higher the intraclass correlation coefficients the better the reproducibility of the method. A $\kappa$ of 1 reflects perfect reproducibility. The intraclass correlation coefficient is a widely accepted measure of reliability and is considered more appropriate than older methods such as $\chi^{2}$, percentage agreement, product moment correlation or Yule's Y. ${ }^{1516}$

The effects of graded changes in $\mathrm{FiO}_{2}$ on exhaled NO and systemic haemodynamics were assessed by repeated measure ANOVA. Post hoc comparisons were carried out using paired $t$ tests. The level of significance was set at $\mathrm{p}=$ 0.05. Data are presented as means (SE).

\section{Results}

The baseline value of $\mathrm{PaO}_{2}$ in the pilot experiment was $92(4) \mathrm{mm} \mathrm{Hg}(12.3(0.5) \mathrm{kPa})$. A mixture of $10 \% \mathrm{O}_{2}+90 \% \mathrm{~N}_{2}$ caused moderate hypoxia with a $\mathrm{PaO}_{2}$ of 45 (2) $\mathrm{mm} \mathrm{Hg}(6.0$ $(0.3) \mathrm{kPa}$ ). In contrast, $100 \% \mathrm{O}_{2}$ raised the $\mathrm{PaO}_{2}$ to $491(24) \mathrm{mm} \mathrm{Hg}(65.5(3.2) \mathrm{kPa}$ ).

Exhaled NO levels at baseline, after the fourth breathing period, and at the end of the study were 31 (3) ppb, 30 (3) ppb, and 28 (2) $\mathrm{ppb}$, respectively (NS). The intraclass correlation coefficient as calculated from these results was 0.63 .

The effect of inhalation of the gases with different $\mathrm{FiO}_{2}$ on exhaled NO is shown in fig 1. There was a positive correlation between changes in $\mathrm{FiO}_{2}$ and exhaled NO levels $(\mathrm{p}=$ 0.0012 , ANOVA), with 26 (3) ppb at an $\mathrm{Fio}_{2}$ of 0.1 and 39 (4) ppb at an $\mathrm{FiO}_{2}$ of 1.0 . An $\mathrm{FiO}_{2}$ of 0.1 , however, did not significantly reduce exhaled NO compared with baseline, as evidenced from post-hoc comparisons. 
Systolic blood pressure was 127 (12) $\mathrm{mm}$ $\mathrm{Hg}$, diastolic blood pressure was 79 (6) $\mathrm{mm}$ $\mathrm{Hg}$, and pulse rate was 79 (11) beats/min at baseline. Systemic haemodynamics showed only minor changes during inhalation periods (data not shown). A significant increase in pulse rate to 87 (7) beats/min was observed only during inhalation of a gas mixture with an $\mathrm{FiO}_{2}$ of 0.1 ( $p=0.023$ compared with baseline).

\section{Discussion}

The results of this study show that NO in the exhaled air is dependent upon oxygen tension. Hyperoxia during $100 \% \mathrm{O}_{2}$ breathing resulted in an approximately $25 \%$ increase in exhaled NO levels compared with baseline. In contrast, hypoxia only slightly reduced exhaled NO. The latter might be caused by at least two phenomena. On the one hand, the reproducibility of our test system may limit the sensitivity to detect small changes in exhaled NO concentration and, on the other, a study in humans is limited to moderate hypoxia and we cannot exclude the possibility that a more pronounced hypoxia would have resulted with lower concentrations of $\mathrm{NO}$ in the exhaled air.

It has already been observed in buffer perfused rabbit lungs that hypoxia decreases exhaled NO. ${ }^{11}$ In the isolated pig lung hypoxia produced an increase in pulmonary vascular resistance and a fall in exhaled levels of NO. ${ }^{1012}$ The mechanism by which hypoxia and hyperoxia influence exhaled levels of NO remains unclear. An inhibition of NO synthase by pulmonary hypoxia is unlikely because the vasoconstrictor response to hypoxia is intensified by NO synthase inhibition. ${ }^{17}$ It has been speculated that hypoxia limits the availability of oxygen for NO synthesis, ${ }^{12}$ which is in keeping with the finding that hypoxia inhibits NO synthase through oxygen depletion. ${ }^{18}$ However, our results support the concept that endogenously generated $\mathrm{NO}$ is involved in hypoxic pulmonary vasoconstriction.

For interpretation of our data it must be considered that the exact origin of $\mathrm{NO}$ in exhaled air in healthy humans has not yet been determined. High concentrations of NO have been observed in paranasal sinuses ${ }^{19}$ and it is assumed that exhaled NO to some degree reflects NO derived from the upper airways. ${ }^{20}$ The endogenous source of exhaled $\mathrm{NO}$ is reflected by the reduction in expired $\mathrm{NO}$ following inhalation ${ }^{32}$ and intravenous administration of NO synthase inhibitors ${ }^{22-25}$ and the increase after orally ${ }^{26}$ and intravenously ${ }^{24}$ administered L-arginine. The comparatively high levels of NO measured with our system in exhaled air may be caused by the fact that, on the one hand, autoinhalation of NO, but not the nasal contribution of $\mathrm{NO}$, were avoided by the use of a noseclip and, on the other, breath holding increases NO levels.
In conclusion, we have shown that the NO concentration in exhaled air in healthy humans is dependent on oxygen tension. Hyperoxia increases the level of exhaled NO, which indicates increased pulmonary NO production. The mechanism behind this phenomenon remains to be elucidated.

1 Gustafsson LE, Leone AM, Persson M, Wiklund NP, Moncada S. Endogenous nitric oxide is present in the exhaled air of rabbits, guinea-pigs and humans. Biochem Biophys Res Commun 1991,181:852-7.

2 Borland C, Cox Y, Higenbottam T. Measurement of exhaled nitric oxide in man. Thorax 1993;48:1160-2.

3 Kharitonov SA, Yates D, Robbins RA, Logan Sinclair R, Shinebourne E, et al. Increased amount of nitric oxide in

Barnes PJ, Belvisi MG. Nitric oxide and lung disease. Thorax 1993;48:1034-43.

5 Barnes PJ, Kharitonov SA. Exhaled nitric oxide: a new lung function test. Thorax 1996;51:233-7.

6 Kimberley B, Nejadnik B, Giraud GD, Holden WE. Nasal contribution to exhaled nitric oxide at rest and during breathholding in humans. Am $\mathcal{7}$ Respir Crit Care Med 1996; 153:829-36.

7 Persson MG, Wiklund P, Gustafsson LE. Endogenous nitric oxide in single exhalations and the change during exercise. Am Rev Respir Dis 1993;148:1210-4.

8 Marshall BE. Hypoxic pulmonary vasoconstriction. Acta Anaesthesiol Scand 1990;34(Suppl 94:)37-41.

9 Shaul PW, Farrar MA, Zellers TM. Oxygen modulates endothelium-derived relaxing factor production in feta pulmonary arteries. Am f Physiol 1992;262:H355-64.

10 Cremona G, Higenbottam T, Takao M, Hall L, Bower EA. Exhaled nitric oxide in isolated pig lungs. 7 Appl Physiol 1995;78:59-63.

11 Grimminger F, Spriestersbach R, Weissmann N, Walmrath $D$, Seeger W. Nitric oxide generation and hypoxic vasoconstriction in buffer-perfused rabbit lungs. F Appl Physiol 1995;78:1509-15.

12 Nelin LD, Thomas CJ, Dawson CA. Effect of hypoxia on nitric oxide production in neonatal pig lung. Am f Physiol 1996;271:H8-14.

13 Pitkin AD, Roberts CM, Wedzicha JA. Arterialised earlobe blood gas analysis: an underestimated technique. Thorax 1994;49:364-6.

14 Jilma B, Kastner J, Mensik C, Hildebrand J, Vondrovec B, Krejcy K, et al. Sex differences in nitric oxide production. Life Sci 1996;58:469-76.

15 Kramer MS, Feinstein AR. Clinical biostatistics. Clin Phar macol Ther 1981;29:111-23.

16 Bartko JJ, Carpenter WT. On the methods and theory of reliability. $\mathcal{f}$ Nerv Men Dis 1976;163:307-17.

17 Persson MG, Gustafsson LE, Wiklund NP, Moncada S, Hedqvist P. Endogenous nitric oxide as a probable modulator of pulmonary circulation and hypoxic pressor reulator of pulmonary circulation and hypoxic pressor
sponse in vivo. Acta Physiol Scand 1990;140:449-57.

18 Rengasamy A, Johns RA. Characterization of endotheliumderived relaxing factor/nitric oxide synthase from bovine cerebellum and mechanisms of modulation by high and low oxygen tensions. F Pharmacol Exp Ther 1991;259: low oxyge $310-6$.

19 Lundberg JON, Weizberg E, Nordvall SL, Kuylenstierna R, Lundberg JM, Alving K. Primarily nasal origin of exhaled nitric oxide and absence in Kartagener's syndrome. Eur Respir f 1994;8:1501-4.

20 Schedin U, Frostell C, Persson MG, Jakobsson J, Andersson G, Gustafsson LE. Contribution from upper and lower airways to exhaled endogenous nitric oxide in humans. Acta Anesthesiol Scand 1995;39:327-32.

21 Yates DH, Kharitonov SA, Robbins RA, Thomas PS, Barnes PJ. Effect of a nitric oxide synthase inhibitor and a glucocorticosteroid on exhaled nitric oxide. Am f Respir Crit Care Med 1995;152:892-6.

22 Krejcy K, Schmetterer L, Kastner J, Nieszpaur-Los M, Monitzer B, Schütz W, et al. Role of nitric oxide in hemostatic system activation in humans. Arterioscler Thromb Vasc Biol 1995; 15:2063-7.

23 Schmetterer L, Krejcy K, Kastner J, Wolzt M, Gouya G, Findl $\mathrm{O}$, et al. The effect of systemic nitric oxide-synthase Findl $\mathrm{O}$, et al. The effect of systemic nitric oxide-synthase
inhibition on ocular fundus pulsations in man. Exp Eye Res 1997;64:305-12.

24 Schmetterer L, Findl O, Fasching P, Ferber W, Strenn K, Breiteneder $\mathrm{H}$, et al. NO and ocular blood flow in patients with insulin-dependent diabetes mellitus. Diabetes 1997 46:653-8.

25 Wolzt M, Schmetterer L, Ferber W, Artner E, Mensik C, Eichler HG, et al. Effect of nitric oxide-synthase inhibition on renal hemodynamics in man: reversal by L-arginine. Am $\mathcal{F}$ Physiol 1997;272:F178-82.

26 Kharitonov SA, Lubec G, Lubec B, Hjelm M, Barnes PJ. $\mathrm{L}$-arginine increases exhaled nitric oxide in normal human subjects. Clin Sci 1995;88:135-9. 